$\begin{array}{ll}\text { Security } & \\ \text { 34.05:650.13.052.8(100:497.7) } & \text { review scientific article }\end{array}$

\title{
COMPARATIVE ANALYSIS OF TRAFFIC CALMING MEASURES BETWEEN DEVELOPED COUNTRIES AND THE REPUBLIC OF MACEDONIA
}

\author{
Snezana Mojsoska, PhD \\ Faculty of Security - Skopje \\ E-mail: smojsoska@gmail.com \\ Nikola Dujovski, PhD \\ Faculty of Security - Skopje \\ E-mail: ndujovski@gmail.com \\ E-mail: Stevco Jolakoski, PhD \\ stevco.jolakoski@mtc.gov.mk
}

\begin{abstract}
Traffic is an extremely important organized social and human activity. Life in the modern society is unimaginable without traffic. Traffic is the result of the level of development of a country, and vice versa, itself it wields pressure on the development of a country's economy. There is a strong association between traffic and the economic development. The development of technology has a profound impact on traffic and the dependency of transport systems on their surroundings in an economic, social and geographical sense. Traffic is among the central topics in all concepts of sustainable development. Traffic safety in the world and in our country is viewed as a fundamental issue that requires a permanent solution. Each day we pay a very high price for the advantages of the modern and dynamic motorized and non-motorized road transport. In support of the increasing traffic safety, in this paper we shall analyse the problem of setting up traffic calming measures in the country. In the comparative analysis through this paper, we recognize that each country has a different approach to the assessment of costs and benefits of traffic calming measures and access to the methods of their installation in urban areas. In most developed countries, such as the United States or the
\end{abstract}


UK, the calculations are based on a designed project comprising different variables. Whereas in Macedonia there is not even one project upon which such installation could be performed, thus proved by the surveys conducted in 54 municipalities and their budgets from which funds are allocated. From the results received from the survey on the installation of traffic calming measures in developed countries and in the Republic of Macedonia, measures will be proposed and taken from the experiences on how to improve or increase traffic safety through traffic calming measures.

Key words: safety, traffic, traffic calming measures, economic significance, developed countries

\section{Introduction}

Technological developments in the twentieth century advanced a complex road network and integrated transport systems, by growing an extremely complex structure of space and time, with a number of features and alternative technologies. The functioning of this system allows operation of the world economy at all levels, but also causes direct and indirect effects, which, from the standpoint of the human community, can be valued as negative. Perception and quantification of these effects is the first step towards economic modelling of costs in traffic. In academic research, there is an opinion that traffic costs include only what the state or the users pay for traffic services. But the terms: effects or traffic costs include a broader set of costs that can be considered in terms of direct and indirect beneficiaries in relation to the society.

Each country has a different approach to the assessment of the cost-benefit of traffic calming measures. In more developed countries such as the United States or the UK, the calculations are based on a project, which comprises different variables. The developed countries have a different approach to calculating the costs for the installation of traffic calming measures. In some countries, these calculations are more than the cost for physical installation of the same, and some calculate all other factors, including the costs for setting up signalization, increasing safety, the cost benefit from reducing the volume of traffic, increasing road interaction of all participants in traffic, hindering the movement of emergency vehicles, and some countries even calculate the benefit to the business community.

This paper analyses the implementation of traffic calming measures in the developed countries and in the Republic of Macedonia. The first section displays examples of surveys conducted in several developed countries on the installation of traffic calming 
measures. The second one covers the analyses of the installation of traffic calming measures in the Republic of Macedonia through a research made by the authors. The third part provides conclusions and recommendations for increasing the safety measures in traffic in the Republic of Macedonia.

\section{Installation of traffic calming measures in developed countries}

According to the research conducted by the Department of Transport of Minnesota (Table 1), the installation of traffic calming measures confirmed their hypothesis that the same lead to increased traffic safety in the sense of reducing the speed of vehicles and decreased volume of vehicles on the streets where they are installed. Regarding the cost of their installation, cost-benefit analysis justifies setting traffic calming measures. Table 1 displays the annual costs and benefits from the installation of traffic calming measures in Minnesota. 
Secuurity

Table 1 - Funds allocated for traffic calming measures in Minnesota ${ }^{54}$

\begin{tabular}{|l|l|l|l|}
\hline $\begin{array}{l}\text { Type of traffic } \\
\text { calming measure }\end{array}$ & Costs & Performance & \\
\hline Chicanes & $\begin{array}{l}5,000 \quad- \\
10,000 \quad \text { USD } \\
\text { by location }\end{array}$ & $\begin{array}{l}\text { Speed reduction by } \\
6 \%\end{array}$ & $\begin{array}{l}\text { Reducing the } \\
\text { volume of traffic } \\
13 \%\end{array}$ \\
\hline Street Narrowing & $\begin{array}{l}50 \text { USD at } \\
30 \mathrm{~cm}\end{array}$ & $\begin{array}{l}\text { Speed reduction from } \\
4 \text { to 22\% }\end{array}$ & $\begin{array}{l}\text { Reducing the } \\
\text { volume of traffic } \\
\text { from 17\% to 48\% }\end{array}$ \\
\hline Bumps & $\begin{array}{l}7,000 \quad \text { USD } \\
\text { per pair }\end{array}$ & $\begin{array}{l}\text { Speed reduction to } \\
15 \%\end{array}$ & $\begin{array}{l}\text { Reducing the } \\
\text { volume of traffic } \\
13 \%\end{array}$ \\
\hline Roundabouts & $\begin{array}{l}3,000 \\
15,000 \text { USD }\end{array}$ & $\begin{array}{l}94 \% \text { reduction of } \\
\text { traffic accidents }\end{array}$ \\
\hline
\end{tabular}

The competent institutions in Minnesota are constantly working on maintaining safer streets and roads. As a complex step, it involves harmonization of all factors, calming traffic, quality of life, living safely and effectively with lower transportation costs ${ }^{55}$.

By request of the citizens of Atlanta to increase traffic safety, the government made a program for setting traffic calming devices as one of the key measures to increase safety. The Atlanta program from 1994, which still applies, covered 436 locations for placement of traffic calming devices, with emphasis on 90 locations.

The installation cost for "traffic calming devices" is 1100 USD per device ${ }^{56}$. While the cost of each device including all supporting elements like markers of the device or signal signs for the presence of traffic calming devices amounts 2,200 USD per device.

${ }^{54}$ Investigating the effectiveness of traffic calming strategies on the driver's behaviour, traffic and speed, 2002, Minnesota Local Road Research Board, Department of Transportation Minnesota, p. $75-80$

${ }^{55}$ Investigating the effectiveness of traffic calming strategies on the driver behaviour, traffic flow and speed, 2002, Minnesota Local Road Research Board, Department of Transportation Minnesota, p. 23 
Securiaty

Table 2 - The Atlanta Program for installation of "traffic calming devices" 57

The Atlanta Program for installation of "traffic calming devices"

\begin{tabular}{|l|l|l|l|}
\hline Municipality & Price & Speed reduction & Included in the price \\
\hline Atlanta & $1100 \$$ & $25 \mathrm{mph}$ & "sleeping policemen" \\
\hline Cobb & $2200 \$$ & $25 \mathrm{mph}$ & "sleeping policemen", signs \\
\hline DeKalb & N / A & $25 \mathrm{mph}$ & "sleeping policemen", signs \\
\hline Gwinnett & $1934 \$$ & $25 \mathrm{mph}$ & "sleeping policemen", signs \\
\hline
\end{tabular}

The following table provides an overview of the products per traffic calming device in Canada. ${ }^{58}$

Table 3 - Standard costs for traffic calming devices ${ }^{59}$

\begin{tabular}{|l|l|}
\hline Type of traffic calming device & Cost \\
\hline Ramps & 1,500 USD per product \\
\hline Light stripes & $10,000-20,000$ USD per lane \\
\hline Traffic circles & $4,000-6,000$ USD \\
\hline "Sleeping policemen" & 2,000 USD per product \\
\hline
\end{tabular}

Source: Litman, T., 1999, Traffic calming benefits, costs and equity impact, Victoria Transport Policy Institute, Canada, p.19

\footnotetext{
${ }^{56}$ Adapted by: Group of Authors, Calming neighborhood traffic with speed humps: Comparing policies and programs in metro Atlanta, 2000, Atlanta

${ }^{57}$ Calming neighbourhood traffic with speed humps: Comparing policies and programs in metro Atlanta, 2000, Atlanta, p 18.
}

${ }^{59}$ Making Streets that Work, City of Seattle (www.ci.seattle.wa.us/npo/tblis.htm), 1996 
The research carried out in Canada concluded that the potential benefits include: road safety, increased comfort and mobility for non-motorized participants, reduced harmful environmental impacts, increased interaction in the neighbourhood, and increased property values. Traffic calming devices can help in creating a beneficial community and in reducing the suburban sprawl. Unlike the United States, in Canada the calculation of costs for traffic calming devices includes the costs for the project, the value of the responsibility, the delay of cars due to speed limitation because of traffic calming devices, redirecting the traffic, arising problems for emergency vehicles and service vehicles, frustration of the drivers who drive at high speed, and problems for cyclists and pedestrians with visual impairments.

The UK government has created policies in order to allow the ministries responsible for road safety to mark the streets as "home zones", i.e. residential streets with limited traffic speed. The devised speed is less than $32,18 \mathrm{~km} / \mathrm{h}$, probably 16,09 $\mathrm{km} / \mathrm{h}$. Signs will be placed at the end points to mark the special status of that part of the street. The designs will include shared space (without pivots), improvement of the space and playground equipment. The federal government distributes funds to the local agencies for planning and implementation. ${ }^{60}$

Traffic calming measures in London, as a representative of the European countries, were first introduced by law in 1865 to limit driving speed to $4 \mathrm{~km} / \mathrm{h}$. The same law was revoked in 1896 allowing vehicles to move up to $12-14 \mathrm{~km} / \mathrm{h}$. In 1903, the new law increased the driving speed to $20 \mathrm{~km} / \mathrm{h}$. In 1990 traffic calming devices were installed which do not allow driving speed over $20 \mathrm{mph}$. Traffic calming devices in London are arranged through the installation of engineering resources which do not affect the psychological attitude of the driver but they physically limit the speed of the car. The costs for installation of traffic calming devices in London vary depending on the type, the number of lanes or the number of compartments and materials to be used. In 1993, the costs for thermoplastic installations were $500-1,500 \mathrm{f}$ pounds sterling. Rough round speed bumps were priced from $€ 2,500-10,000$ and have a three-year lifespan. An undulation or a speed hump costs $£ 50$ per square meter or $£ 5,000$ per 20 square meters.

The costs for traffic calming devices in London, expressed in the unit price per device in 2012, are shown in Table 4.

${ }^{60}$ www.homezonenews.org.uk (accessed on 07.06.2013) 
Securiaty

Table 4 - Costs for traffic calming measures in London ${ }^{61}$

\begin{tabular}{|l|l|}
\hline Measure & Costs \\
\hline Round bump & $400-1,000 €$ per product \\
\hline "Traffic calming device" & $500 €$ \\
\hline Thermoplastic bump & $300-500 €$ \\
\hline
\end{tabular}

Data obtained from selected developed countries shows that each country/region has different costs, depending on the size of the traffic-calming device, on the structure, the construction material, and certainly on the type. Furthermore, each country has a different approach to calculating the costs in order to increase traffic safety by applying traffic calming devices.

\section{ANALYSIS OF SAFETY AND FINANCIAL RESOURCES OF THE MUNICIPALITIES IN THE REPUBLIC OF MACEDONIA FOR INSTALLATION OF TRAFFIC CALMING DEVICES}

Traffic calming devices can be permanent or temporary, depending on the desired effect on the specific location. The Republic of Macedonia has done research on the manner, place and financial resources for the placement of traffic calming devices. The legal acts of the Republic of Macedonia that regulate the placement of traffic calming devices do not provide sanctions or punitive provisions in case of their installation and if the same is against the installation procedure. In order to observe the installation of traffic calming devices in the Republic of Macedonia in economic terms a survey has been conducted in the institutions responsible for such installation, i.e. the municipalities. The research sample, based on a questionnaire, included 52 municipalities from the Republic of Macedonia. The questionnaire was distributed in the same period to all municipalities and was answered within 48 hours.

The municipalities received a questionnaire with the following questions:

> Financial resources in the municipal budget provided for the period from 2008 to 2012 allocated for dealing with traffic calming measures, specifically for the installation of "traffic calming devices";

${ }^{61}$ Department for Transport, 2007, Local Transport Note 1/07, Traffic Calming, London, p.47 


\section{Security}

$>$ How much of these funds ${ }^{62}$ were used by the municipality for installation of traffic calming devices?

$>$ How much was the sufficient amount of these funds to meet the needs according to the planned traffic calming devices?

The analysis displayed in Table 5 shows that investments in traffic calming devices in the period 2008-2012 in the Republic of Macedonia were very low, and most funds were allocated by the City of Skopje, being the largest municipality in the country.

${ }^{62}$ Undoubtedly, if considered 


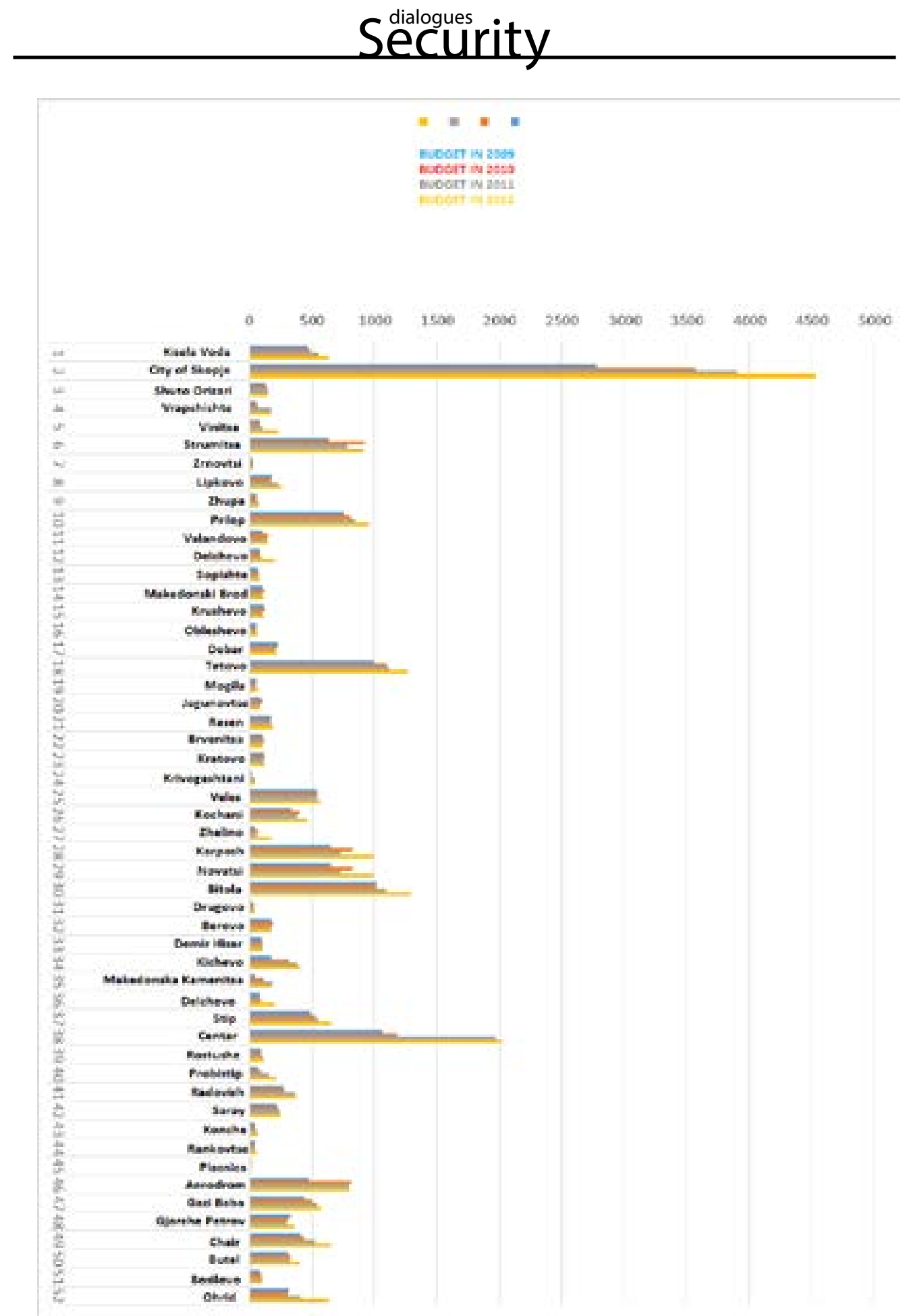




\section{Chart 1 - Allocated funds for traffic calming}

\section{Allocated funds for traffic calming in the municipalities}

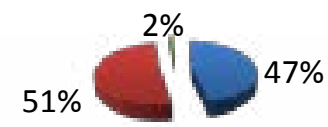

According to the results presented in the chart, we see that more than half or $51 \%$ of the municipalities responded that they did not have separate funds to implement traffic calming measures in the period from 2008 to $2012,47 \%$ said they had funds allocated for that purpose, and the remaining $2 \%$ gave no answer to that.

According to a detailed survey of municipalities, which in the observed period set or did not set traffic calming measures, i.e. "traffic calming devices", it is evident that road safety in some municipalities, in terms of protection of people, is at a very low level. In more than half of the municipalities traffic-calming devices were not installed, which from a security standpoint puts the residents in a structure predisposed to risks.

When we talk about traffic, safety there is no rule that smaller or larger municipalities have more or less a safe environment. A very small part of the small municipalities have not set up this type of elements, but the column of municipalities that did not install "traffic calming measures" includes major municipalities as: the Municipality of Karposh, Demir Hisar, Kratovo, Tetovo, Valandovo, Makedonski Brod, that still have the necessity to implement measures to protect the users. 
Table 6 - Display of funds allocated for installation of "traffic calming measures" $2008-2012^{63}$ (in denars)

\section{Chart Title}

2000000.00

13579111315171921232527293133353739414345474951

-Amount of allocated funds by the municipalities 2008

Amount of allocated funds by the municipalities 2009

Amount of allocated funds by the municipalities 2010

From the diagram above it is evident that very few municipalities, only 13, have invested in the installation of "traffic calming measures". Most of them did not invest at all, whereas, those that invested, i.e. 7 municipalities invested only for one year, while the remaining 6 allocated funds for each year of the observed period, for the purpose of setting or restoring traffic calming measures.

Chart no. 2 shows the amount of funds invested which were planned for "traffic calming measures" by municipality.

The following chart shows the situation of invested funds in 2012 by the municipalities, which took part in the research sample for the dissertation.

${ }^{63}$ It is important to note that some municipalities have not specified the amount of funds allocated in the observed period for setting up "traffic calming measures", though having installed this type of traffic calming measures. 
Chart 2 - Invested funds for the installation of "traffic calming measures" in 2012

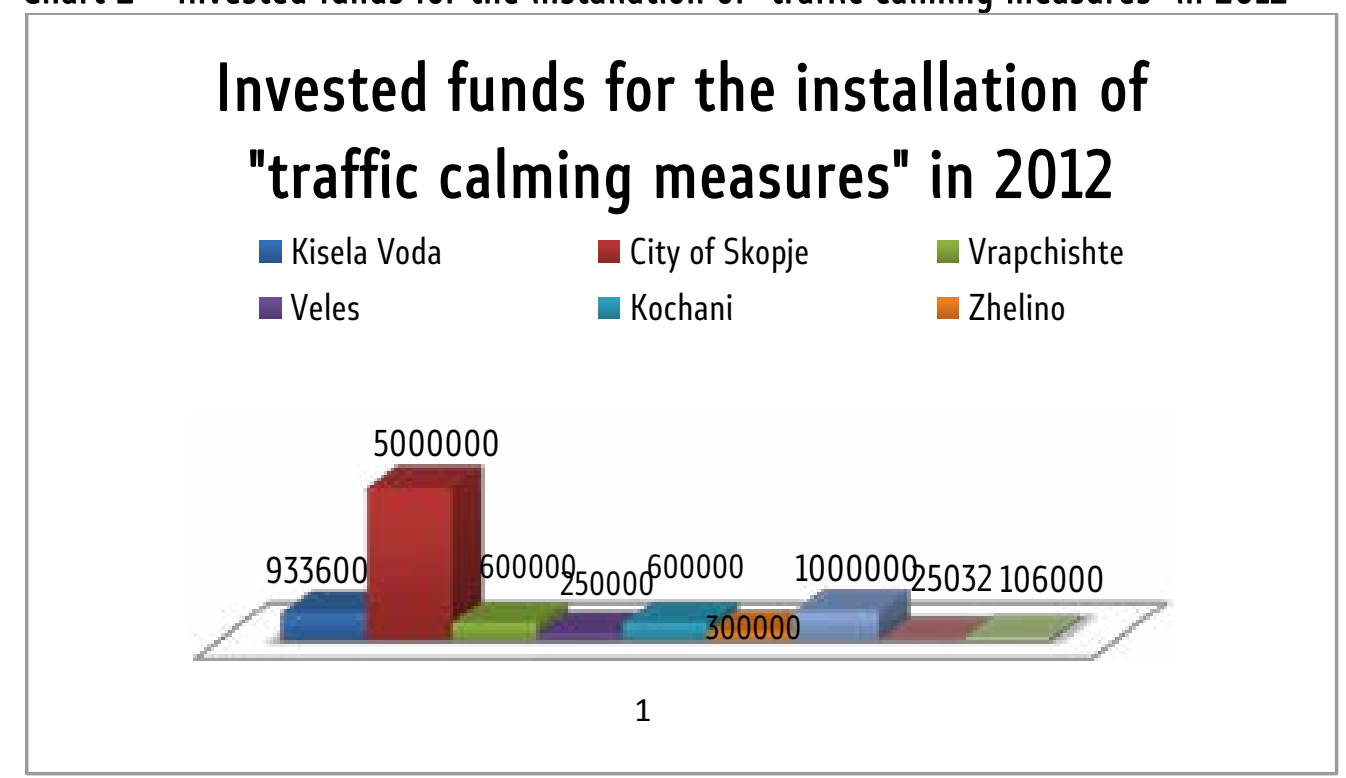

In 2012, the Municipality of the City of Skopje made major investments in the implementation of traffic calming measures, i.e. 5,000,000.00 denars; the Municipality of Bitola invested 1,000,000.00 denars; while the remaining municipalities made smaller ventures. The amount of funds provided by the municipalities Kisela Voda, Ohrid and Berovo remained unchanged over the past years. On the other hand, those countries which made no investments in the past years for protection measures by applying "traffic calming measures", yet in 2012 they decided to implement traffic calming measures, whereas, the Municipality of Vrapchishte endowed 600,000.00 denars, the Municipality of Veles provided 250,000.00 denars, Kochani Municipality supplied 600,000.00 denars, and the Municipality of Zhelino spent 300,000.00 denars for that purpose.

Therefore, we can conclude that the municipalities, on a large scale, did not invest in the installation of traffic calming measures in order to increase traffic safety on the territory of the Republic of Macedonia. 
Chart 3 - (Un) Used planned funds for installation of "traffic calming measures" in the municipalities

\section{(Un)Used planned funds for installation of "traffic calming measurees " in the municipalities}

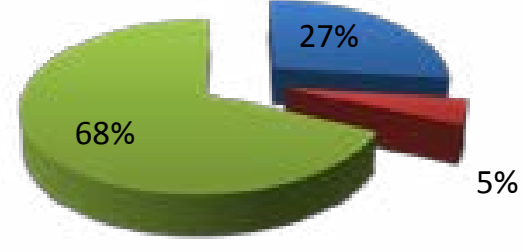

It may be noted that $68 \%$ of the municipalities covered in the research sample did not answer this question, which actually means that funds were not used for installing traffic calming devices, nor a budget had been provided for such purpose. Only $27 \%$ of the municipalities stated the planned funds were used for installation of the said devices, and the remaining $5 \%$ said they had planned funds for this purpose, but the same were not used in the observed period in the study.

Chart 4 - (In) Sufficient funds for installation of traffic calming measures or "traffic calming devices" in the period 2008 - 2012

(In)Sufficient funds for installation of traffic calming measures or "traffic calming devices" in the period

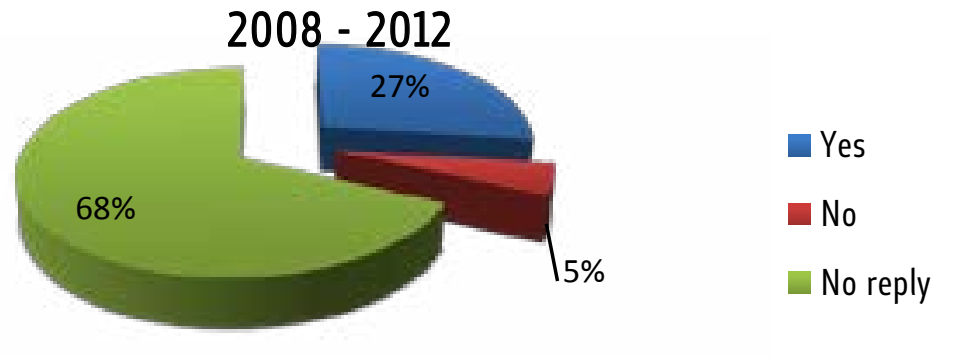




\section{Securitity}

According to the data presented in the graph, we can point out that $68 \%$ of municipalities did not answer this question, indicating they had provided funds for the purpose of traffic calming devices or they did not use them so they would learn whether they were sufficient or not.

$27 \%$ said that funds allocated for the installation of "traffic calming measures" were sufficient for the realization of the plan, while the remaining $5 \%$ said they needed a larger budget and did not fulfil the plans completely.

Hence, we notice that the majority of municipalities that in the period from 2008 to 2012 allocated funds for installing traffic calming devices, submitted a request to the Ministry, meaning, a total of 21 municipalities in the said period had projected funds for the aforementioned devices, 16 of which submitted requests to the Ministry of Transport and Communications under which permission they can place road humps i.e. "sleeping policemen".

\section{Conclusion}

The development of traffic and the high rate of vehicular traffic, with all the important benefits of meeting the need for mobility of residents in cities, still, is causing certain drawbacks among which generally stand out traffic accidents.

According to the analysis of road accidents in the Republic of Macedonia in the period from 2000 to $2007^{64}$, the number of casualties in traffic accidents is increasing each year. In Europe and in other world countries such as America and Australia, there is a high prevalence of traffic calming measures, where often the procedure of planning and designing the concept of traffic calming is applied. The designed concept is applied to city streets with severe traffic congestion, and also near institutions, kindergartens and schools, as well as in locations where there is increased movement of pedestrians. The results show that over the years the total number of persons killed in traffic accidents in the developed countries is decreasing.

Finances play a major role in traffic; not investing in traffic infrastructure affects the quality of the roads resulting in damaged vehicles and greater opportunities for accidents. However, investments are needed, not only for road maintenance, but also for

${ }^{64}$ National Strategy of the Republic of Macedonia for improving road traffic safety 2009 - 2014, Republic of Macedonia, November 2008 
the safety elements as signs and traffic calming devices. The countries including all their regions and sub-regions have to take account of the allocated funds for this purpose.

In terms of funds applied for installation of traffic calming devices in Europe and worldwide, it can be pointed out that countries allocate funds for this purpose, but there is no available data on how many of these devices are installed annually in order to calculate the real financial framework allocated to increase traffic safety.

In urban areas of the major cities in our country, there are "sleeping policemen" that direct drivers to limit their driving speed and increase safety of pedestrians. The number of installed traffic calming devices in the country does not meet the security standards for the preservation of road safety and protection of its participants.

The results of an empirical study point out that it would be of great significance to carry out changes of the Rules for Traffic Safety that will impose mandatory installation of a number of "traffic calming devices" in each municipality of the country including an analysis of the number of inhabitants and critical locations, which will determine the number of required resources of its kind. Not all municipalities have sufficient financial resources for setting up these funds, and I feel it is necessary to think that the state should fund the installations with emphasis on the municipalities that have not yet instated traffic calming measures. After the completion of the survey, the Municipality of the City of Skopje in 2012, suggested to draw rules for traffic calming measures and to define the traffic calming devices, or add the following traffic calming measures to the existing rules for signalling and road equipment:

- Raised pedestrian crossings at the height of the curb

- Raised platforms at intersection zones at the height of the curb

- Raised circular platform at intersections (for mini roundabouts)

- Speed cushions

- Introducing central refuges (small islands) and street narrowing

- Introducing chicanes

For application of the measures above it is mandatory they be regulated by rules. 


\section{Securialoges $r i t y$}

\section{References}

1. Adapted by: Group of Authors, Calming neighbourhood traffic with speed humps: Comparing policies and programs in metro Atlanta, 2000, Atlanta

2. Department of Transport, 2007, Local Transport Note 1/07, Traffic Calming, London, p.47

3. Investigating the effectiveness of traffic calming strategies on the driver's behaviour, traffic flow and speed, 2002, Minnesota, Local Road Research Board, Department of Transportation Minnesota, p.23

4. Litman, T., 1999, Traffic Calming Benefits, Cost and Equity Impacts, Victoria Transport Policy Institute, Canada, p.19

5. Making Streets that Work, City of Seattle (www.ci.seattle.wa.us/npo/tblis.htm), 1996

6. www.homezonenews.org.uk (accessed 07.06.2013) 